\title{
Performance of recycled PET and conventional PES fibers in case of water transport properties
}

DOI: $10.35530 / \mathrm{IT} .071 .06 .1691$

\section{ABSTRACT - REZUMAT}

\section{Performance of recycled PET and conventional PES fibers in case of water transport properties}

In recent years the researches on liquid moisture transport properties of fabrics have great importance. Especially for the sport garments, fabric structure should led liquid moisture to transfer from skin surface to the outer layers. Special fibers and fabric structures were designed including channelled fibers and micro fiber productions to contribute higher capillary transport capability to the textile surface. Polyester fibers are used for this purpose frequently. Due to the increase in the demand of sustainable textiles, production and consumption of recycled polyester fibers are increasing recently. They are expected to have adequate mechanical properties to fulfil requirements. In this study, liquid moisture transfer properties of the polyester and r-PET fabrics were investigated. For this purpose, knitted fabrics produced from $100 \%$ polyester and $100 \%$ r-PET yarns were used. Dynamic liquid transport properties, capillary transfer property, drying rate and water absorption capacity of these surfaces were measured. According to the results, it was concluded that both fabrics were identified as "good" by using "Moisture Management Tester", in case of liquid moisture transfer properties. No significant difference was determined between water vapour permeability values. Static immersion test is helpful in order to determine wettability for the identification of sensitive differences and as a conventional method, vertical wicking test is a good indicator while distinguishing capillarity differences. It was found that $r$-PET fabric has better results than PES fabric, in case of absorption rate, wettability, drying rate and capillarity.

Keywords: r-PET, recycled fiber, moisture management, water vapour permeability, liquid moisture transfer, capillarity drying rate, evaporation speed

\section{Performanța fibrelor de PET reciclat și a fibrelor de PES convențional din punctul de vedere al proprietăților de transport al apei}

În ultimii ani, cercetările cu privire la proprietățile de transport al umidității materialelor textile au o mare importanță. În special pentru articolele de îmbrăcăminte sportive, structura materialului textil ar trebui să ajute la transferul umidității de pe suprafața pielii către straturile exterioare. Au fost proiectate structuri speciale de fibre și de materiale textile, inclusiv fibre multicomponente și microfibre pentru a spori capacitatea de transport capilar prin suprafața textilă. Fibrele de poliester sunt utilizate frecvent în acest scop. Datorită creșterii cererii de materiale textile durabile, producția și consumul de fibre de poliester reciclat sunt în continuă creștere. Se așteaptă ca acestea să aibă proprietăți mecanice adecvate pentru a îndeplini cerințele. În acest studiu, au fost investigate proprietățile de transfer al umidității în cazul materialelor textile din poliester și din r-PET. În acest scop, au fost utilizate tricoturi realizate din fire de $100 \%$ poliester și de 100\% r-PET. Au fost determinate proprietățile dinamice de transport al lichidului, transferul capilar, viteza de uscare și capacitatea de absorbție a apei pe aceste suprafețe. Conform rezultatelor, s-a ajuns la concluzia că ambele materiale textile sunt „adecvate”, prin utilizarea „Testerului de control al umidității”, în cazul proprietăților de transfer a umidității. Nu s-a determinat nicio diferență semnificativă între valorile permeabilității la vaporii de apă. Testul de imersie statică este util pentru a determina umectabilitatea pentru identificarea diferențelor sensibile și, ca metodă convențională, testul de absorbție verticală este un bun indicator, distingând în același timp diferențele de capilaritate. S-a constatat că materialele textile din r-PET înregistreează rezultate mai bune decât materialul textil din PES, în cazul ratei de absorbție, umectabilității, ratei de uscare și capilarității.

Cuvinte-cheie: r-PET, fibră reciclată, controlul umidității, permeabilitatea la vapori de apă, transferul de umiditate, capilaritate, viteza de uscare, viteza de evaporare

\section{INTRODUCTION}

Clothing is one of the most important and fundamental need of the humans. The initial aim of the clothing is to protect the body from uncomfortable environment such as warm, cold, wind, injures, chemicals etc. However, the recent researches revealed that consumers meet their clothing requirements according to their life conditions that is more dynamic and comfortable [1]. As a result, changing expectations of the consumers brought the concept of "comfort".

Continuous dynamic interaction of the garments along with the body movement is one of the important factors for perception of the comfort. Therefore skin temperature, sweating rate and moisture content on skin continuously change during the wearing duration. These effects cause mechanical and thermal 
warnings. These warnings define the users comfort perception [2].

Body generates sweat in order to adjust the body temperature. As the action is low and the environmental heat is in a normal level, there is a constant moisture transfer between the environment and the pores of the skin and the sweat is released in vapour form. While the sweating is slow, it cannot be felt. However, if the heat, which is generated due to the increased action, is not given to the environment, the skin produces sweat to keep the body temperature in $37^{\circ} \mathrm{C}$ constant level. In order to evaporate the liquid sweat from the skin surface, it is necessary to take the heat energy from the body. By the way, the body temperature decreases.

Liquid moisture transport properties of the fabric in multi-dimensions, referred to as moisture management properties and that influence the human perception of moisture sensations and comfort significantly [3, 4].

The term 'moisture management fabrics' can be defined as textile fabrics which provide the control of the movement of body water (e.g. sweat) and moisture in such a way that they are transported away from the skin to the outer surface of the fabric where they can evaporate quickly [5, 6].

Niwa stated that liquid water (sweat) absorptivity of fabrics is more important than water vapour permeability in determining the comfort factor of fabrics [7]. Avcl investigated socks, which were knitted with using various fiber types. It was determined that the wet behaviour properties of socks are affected directly by fiber type [8]. Marmaralı and Oglakcıoglu found that production parameters like raw material (fiber and yarn specialties), fabric structure (construction, density, thickness, weight, etc.) and finishing applications have important effects on the thermal comfort specialties [9]. According to Matsudaira and Kondo, by means of grooved or non-grooved hollow in the fibre, space ratio and surface area of the fibres increase and by this way more water could be absorbed by polyester fibres [10]. Ozdil et al. analysed the moisture management properties of different materials such as cotton, polyester and wool. They investigated also same yarn count polyester with different filament fineness and found that the moisture transfer properties of polyester yarns from finer filaments are higher [11].

In a study carried out by Süpüren et al. the moisture management properties and the changes of the thermal absorptivity values of a special double-face structure were investigated and it was revealed that different moisture transport properties can be achieved by using different yarn settlements in double-face fabric construction [12]. Wardman and Abdrabbo developed an instrument that uses the image processing technique to exhibit the effect of oxygen plasma treatment on two polyester fiber types (polylactic acid and standard polyester) and its influence on their wetting characteristics [13]. In a study carried out by Ozdil N. et al., moisture transport properties of knitted fabrics, which were knitted from cotton yarns produced with using various yarn twists and yarn counts were investigated. It was pointed out that yarn count and yarn twist has important effect on the fabric moisture transport $[14,15]$.

Since moisture transmitting property of fabric is a key factor that affects textile and clothing comfort, many researchers have studied on this subject comprehensively. Although there are various studies in the literature on moisture management properties of natural and synthetic textile materials, recycled textile materials have not been investigated yet.

Consumption of textile fibers has increased with the overpopulation; it is clear that environmental problems of textile industry increased highly in recent years. For that reasons, finding new solutions is expected from the textile industry to reduce these environmental problems they have caused. In this situation, recycling is the most important topic to be focused on to extend the lifecycle of the materials used.

In reference to environmental approach, waste of a product should be used for producing the same product. Because this way, it will gain primary raw material characteristics again and therefore its life cycle will be longer. However, higher contamination in the recycled polymers and lower viscosity are the restrictions prevent using PET flakes as raw material of PET bottle production. PET flakes are produced for secondary textile products like as carpet bottoms, sleeping bags, pillows and insulation materials in the past but these recycled fibers are being used in garment industry recently. Therefore, using recycled PET fibers in apparel industry can extend their life cycle and make them primary raw material for this industry. When it is considered that the highest consumption of PET polymer in the world is for filament and staple fiber production, it is clear that, it will present environmental advantages [16-19].

r-PET fibers are obtained by recycling of PET bottle wastes. Firstly, PET bottle wastes are separated from the other wastes; then they are broken into flakes, washed and dried respectively before spinning process. PET flakes are converted into fibers using chemical and mechanical methods. PET is degraded into oligomer or monomer form and again a polymerization occurs in chemical method. In mechanical method, PET flakes are melted and r-PET fibers are obtained by melt-spinning process [19-21].

These fibers have economic advantages because of the lower raw material cost. They also have lower energy consumption and low carbon emission in production stage. Therefore, it can be concluded that, r-PET fibers are environmentally friendly fibers [17, 19, 20, 22]

Nowadays, recycled products are being used in many areas and designers in world are accountable for waste production for downstream products such as clothes and interior finishing [23].

As it can be seen, due to the increasing conscious on sustainable materials and products, recycling of textiles is becoming more common. However, moisture and liquid transmission properties that is essential for thermal comfort characteristics of the fabrics. These characteristics of recycled materials have not been 
investigated in detail. The aim of this study is to examine moisture management and absorptivity properties of these fabrics produced from conventional polyester and r-PET fibers.

\section{MATERIALS AND METHODS}

Polyester and r-PET yarns were used in this experiment. r-PET fibers produced by mechanical methods from PET flakes were supplied. Yarns were produced in Ne 20 yarn count and twist coefficients of the yarns were kept constant $(\alpha=3.6)$ for the spun yarns. The fabrics were knitted in single jersey structure by using Mesdan Lab. knitting machine [24]. The fabrics were conditioned in standard atmosphere conditions $20 \pm 2^{\circ} \mathrm{C}$ and $65 \pm 4 \%$ relative humidity before the tests and the moisture management properties of fabrics were measured by Moisture Management Tester (MMT-SDL Atlas) (figure 1) according to AATCC 195 [25].

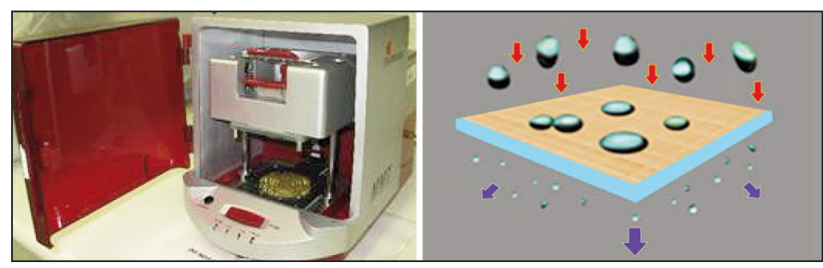

Fig. 1. MMT - Moisture Management Tester Instrument [27]

Some conventional methods can be employed to evaluate the fabric's simple absorbency; wicking and moisture transfer properties, whereas 6 different characteristics such as wetting time, absorption rate, maximum wetted radius, spreading speed, accumulative one way transport capacity and moisture management capacity can be tested by moisture management tester [26].

The specimen is held flat by top and lower sensors at a certain pressure. The computer dynamically records the resistance change between each couple of proximate metal rings individually at the top and lower sensors. A certain weight $(0.15 \mathrm{~g})$ of a predefined test solution (synthetic sweating, AATCC 15) is then put into the sweat gland and imparted onto the top surface of the fabric. The solution will transfer in three directions after arriving on the fabric's top surface: spreading outward on the fabric top surface, transferring through the fabric from the top surface to the bottom surface, and spreading outward on the fabric bottom surface and then evaporating [6]. The parameters measured by the instrument are wetting time $\left(\mathrm{WT}_{\mathrm{t}}\right.$ (top surface) and $\mathrm{WT}_{\mathrm{b}}$ (bottom surface) (seconds)), Absorption Rate (TAR (top surface) and BAR (bottom surface) - (\%/sec)), Maximum Wetted Radius (MWRtop and MWRbottom - $(\mathrm{mm})$ ), Spreading Speed $\left(\mathrm{SS}_{\text {top }}\right.$ and $\left.\mathrm{SS}_{\text {bottom }}-(\mathrm{mm} / \mathrm{sec})\right)$ and Overall Moisture Management Capacity (OMMC).

Overall Moisture Management Capacity (OMMC) is an index to indicate the overall capability of the fabric to manage the transport of liquid moisture and calculated as:
OMMC $=0.25$ BAR + 0.5 OWTC + $0.25 S_{S_{\text {bottom }}}$

where BAR is the absorption rate, OWTC is the oneway transport capacity, and $\mathrm{SS}_{\mathrm{b}}$ is the spreading/drying rate [27]. The larger the OMMC is the higher the overall moisture management ability of the fabric [6, 11, 14, 15, 27-29].

In order to analyse the change in surface properties of the fibers, SEM images of the fibers were also taken by using a scanning electron microscope (Hitachi TM-1000).

Water vapour permeability of the fabrics was tested by Permetest instrument. The instrument provides measurements according to ISO Standard 11092. The Permetest instrument can be considered as a small-scale "skin model", which simulates dry and wet human skin in terms of its thermal feeling and serves for determination of water vapour and thermal resistance of fabrics [29].

In order to determine wicking properties of the fabrics, vertical wicking test was conducted. Capillary forces in the pore structures of the medium govern the liquid transport through the pores. Wettability and wickability are two important phenomena related to liquid transport in fabrics. Wetting is known as the displacement of fiber-air interface with fiber-liquid interface and wicking is the transport of fluid which flows in a porous structure, by means of capillary forces. BS 3424-18, the standard test method was used for vertical wicking. A strip of fabric to be tested was suspended vertically into an infinite liquid reservoir. The rise of the liquid on the specimen versus time was recorded and liquid movement speed is calculated. A little dye was added to make the tracking of the movement of water easy.

There is a growing market demand for sportswear with moisture management properties. The drying rate of fabric demonstrates the overall effectiveness of sweat removal by evaporation. Quick dry and fast wicking functions are key features of moisture management fabric. A slow drying fabric could adversely affect the thermal comfort of a highly active wearer who sweats excessively. Measurement of drying rate has become one of the important tests for studying the performance of moisture management fabrics. In order to measure the drying capability of the fabrics testing conditions were chosen as $33 \pm 2^{\circ} \mathrm{C}$ temperature. The $200 \mathrm{~mm} \times 200 \mathrm{~mm}$ square fabric specimen was put on the plate of the balance, and the drying weight was recorded as $W_{f}(\mathrm{~g})$. The weight of water added to the fabric is equal to $30 \%$ of the dry sample weight before testing, designated $W_{o}(\mathrm{~g})$. The change in the amount of water $W_{i}(\mathrm{~g})$ was recorded every 2 minutes continuously for 12 minutes. "Water Evaporating Rate" (WER) was calculated by equation (2) to express the change of water weight remained in the specimen over time, to draw the evaporating curve from $100 \%$ to $0 \%$.

$$
\operatorname{WER}(\%)=\frac{\left(W_{o}-W_{i}\right)}{\left(W_{o}-W_{f}\right)} \times 100 \%
$$


In this study water absorbency time was also determined according to TS EN 14697 [30]. Water absorbency time is the time required to completely immersed of the fabric into the water. Experimental samples were cut in $(100 \pm 1) \mathrm{mm} \times(100 \pm 1) \mathrm{mm}$ sizes, and each of sample was put into the water and the time elapsed to thoroughly immerse the sample was noted which is defined as absorbency time. The test was repeated for 5 times.

In this study, static immersion method was used to evaluate water absorption capacity [31]. In the test weighed samples were immersed in water and calculated the water absorption in terms of following equation:

$$
\text { Water Absorption Capacity }=\frac{\left(M_{W}-M_{D}\right)}{M_{D}} \times 100
$$

where $M_{D}$ is mass of fabric before immersion ( $\mathrm{g}$ ) and $M_{W}$ - mass of fabric after immersion $(\mathrm{g})$.

In this test, mean absorbency time identifies wettability of the fabrics and water absorption capacity indicates hydrophility. Higher the water absorption capacity means higher the hydrophility.

\section{RESULTS AND DISCUSSION}

Moisture management capacity of the fabrics

Moisture management properties of the fabrics are given in table 1.

After the measurements, results of fabrics produced from conventional and recycled fibers were evaluated statistically by independent samples t-test with the significance level of $\alpha=0.05$. Results of Independent Sample T-Test are given in table 2 .
According to the results of two variable comparisons, difference between top absorption rate values was found statistically significant. That means, there is an absorption rate difference between the fabrics produced from r-PET and conventional PES fibers. However, the differences between the other liquid moisture transfer properties such as wetting time, max wetted radius and spreading speed measured by MMT tester were not found statistically significant. As the SEM images given in figure 2 analysed, damages in the surface morphology can clearly be seen. r-PET fibers are produced by mechanical recycled method using bottles. Due to the contamination of PET flakes and re-heating process, molecular weight and tensile properties of the macromolecules change. For this reason, surface of the fibers become rougher. As the surface roughness increases, surface area of the fibres also increases. As a result, wicking and wetting property of the material changes. Therefore, water transfer properties of the fabrics are expected to be changed. In MMT test parameters, it can be seen in top absorption rate value. However, in case of other test parameters, the distinguishing transfer properties of these two fibers could not be clearly detected.

According to the water location vs time graphs given in figure 3 , it can be determined that maximum wetted radius value of PES and r-PET are close to each other. Although, the wetted radius of outer surface is a bit higher for r-PET fabric, the difference between the values (table 2) was found insignificant.

According to the Overall Moisture Management

\begin{tabular}{|c|c|c|c|c|c|c|c|c|c|}
\hline \multicolumn{10}{|c|}{ MOISTURE MANAGEMENT PROPERTIES OF THE FABRICS } \\
\hline Materials & $\begin{array}{c}\text { Wetting } \\
\text { time top } \\
\text { (sec) }\end{array}$ & $\begin{array}{l}\text { Wetting } \\
\text { time } \\
\text { bottom } \\
\text { (sec) }\end{array}$ & $\begin{array}{c}\text { Top } \\
\text { absorption } \\
\text { rate } \\
(\% / \mathrm{sec})\end{array}$ & $\begin{array}{c}\text { Bottom } \\
\text { absorption } \\
\text { rate } \\
(\% / \mathrm{sec})\end{array}$ & $\begin{array}{c}\text { Top max } \\
\text { wetted } \\
\text { radius } \\
(\mathrm{mm})\end{array}$ & \begin{tabular}{|c|} 
Bottom \\
max wetted \\
radius \\
$(\mathrm{mm})$
\end{tabular} & $\begin{array}{c}\text { Top } \\
\text { spreading } \\
\text { speed } \\
(\mathrm{mm} / \mathrm{sec})\end{array}$ & \begin{tabular}{|c|} 
Bottom \\
spreading \\
speed \\
$(\mathrm{mm} / \mathrm{sec})$
\end{tabular} & OMMC \\
\hline PES & 7.96 & 8.02 & 15.37 & 36.62 & 15 & 13.33 & 1.19 & 1.22 & 0.52 \\
\hline r-PET & 7.34 & 7.88 & 58.9 & 38.42 & 15 & 16.25 & 0.88 & 0.91 & 0.53 \\
\hline
\end{tabular}

Table 2

SIGNIFICANCE VALUES OF INDEPENDENT SAMPLE T-TEST

\begin{tabular}{|l|c|}
\hline \multicolumn{1}{|c|}{ Measured parameters } & Significance (p) \\
\hline Wetting Time top(sec) & 0.629 \\
\hline Wetting Time Bottom (sec) & 0.918 \\
\hline Top Absorption Rate $(\% / \mathrm{sec})$ & $0.017^{*}$ \\
\hline Bottom Absorption Rate $(\% / \mathrm{sec})$ & 0.886 \\
\hline Top Max Wetted Radius (MM) & 1.000 \\
\hline Bottom Max Wetted Radius (MM) & 0.066 \\
\hline Top Spreading Speed (mm/sec) & 0.460 \\
\hline Bottom Spreading Speed (mm/sec) & 0.464 \\
\hline OMMC & 0.851 \\
\hline
\end{tabular}

* Significant according to $\alpha=0.05$ significance level.
Capacity (OMMC) test results, polyester and r-PET fabrics are both categorized in "fast absorbing and quick drying fabrics" by the software of the instrument, since, the pumped test liquid could be transferred from the inner surface to the outer surface.
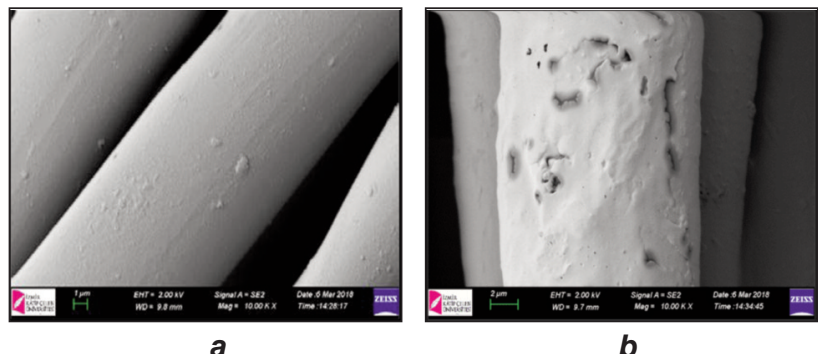

Fig. 2. SEM image of: $a$ - polyester; $b-r-P E T$ fabric coated with $10 \mathrm{~nm}$ of gold using a $15 \mathrm{kV}$ beam 


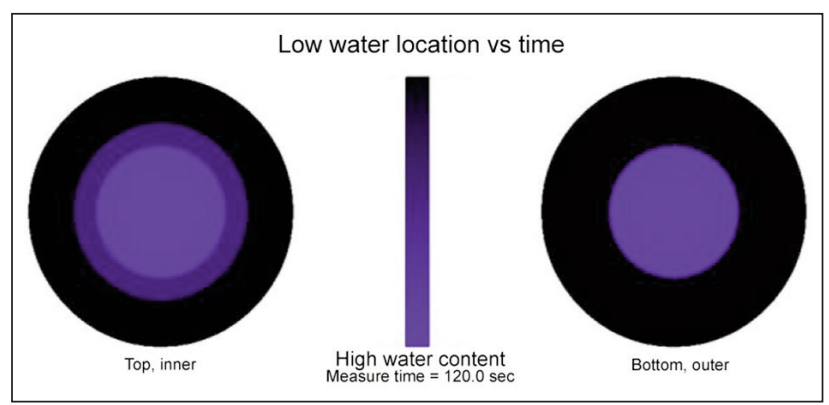

a

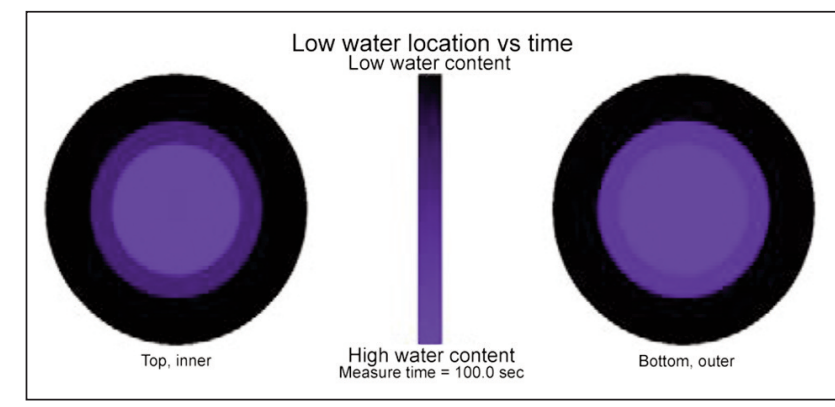

b

Fig. 3. The wetting radius changes in the inner/outer surfaces of fabrics: $a$ - polyester; $b-r$-PET

Table 3

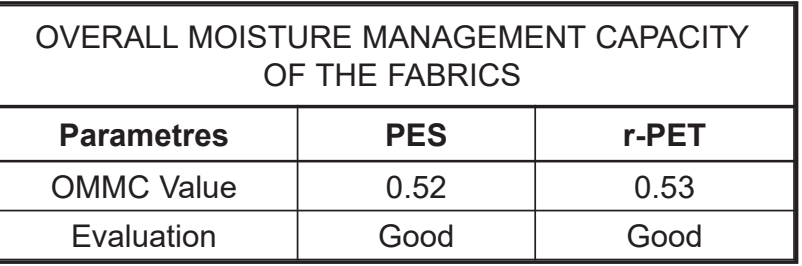

OMMC values, changing between 0 and 1 , which indicates multidirectional liquid transfer ability of the fabrics, are given in table 3 .

According to OMMC evaluation scale, the values are categorized as: 0-0.2 Very poor, 0.2-0.4 Poor, 0.4-0.6 Good, 0.6-0.8 Very good, >0.8 Excellent. In scope of OMMC values of the fabrics, r-PET and polyester fabrics are both identified as "good" in terms of their overall moisture management properties. It indicates that, r-PET fabric has good moisture management characteristics to be used even in garments.

Water absorption capacity of the fabrics

Water absorption capacity and water absorption time values of the fabrics are given in table 4 .

Table 4

WATER ABSORPTION PROPERTIES OF THE FABRICS (STATIC IMMERSION TEST RESULTS)

\begin{tabular}{|l|c|c|c|}
\hline \multicolumn{1}{|c|}{ Parametres } & PES & r-PET & Significance* $^{*}(\mathbf{p})$ \\
\hline $\begin{array}{l}\text { Water absorption } \\
\text { capacity (\%) }\end{array}$ & 4.78 & 4.67 & 0.492 \\
\hline $\begin{array}{l}\text { Water absorption } \\
\text { time (Sec) }\end{array}$ & 5.12 & 3.36 & 0.007 \\
\hline
\end{tabular}

* Significant according to $\alpha=0.05$ significance level.

According to the results, water absorption capacity values of the fabrics were found close to each other. However, water absorption time value of r-PET fabric was found statistically lower than the conventional PES fabric. It is due to the increased surface area of $r$-PET fibers that increases the wettability of these fibers.

\section{Water-vapour permeability of the fabrics}

Water vapour permeability results of the fabrics are given in table 5. According to the results, water

\begin{tabular}{|l|c|c|c|}
\hline \multicolumn{4}{|c|}{ Table 5} \\
\hline \multicolumn{4}{|c|}{$\begin{array}{r}\text { SIGNIFICANCE OF INDEPENDENT SAMPLE } \\
\text { T-TEST }\end{array}$} \\
\hline Characteristic & PES & r-PET & Significance* (p) \\
\hline $\begin{array}{l}\text { Water-vapour } \\
\text { permeability }\end{array}$ & 2.86 & 2.78 & 0.587 \\
\hline
\end{tabular}

* Significant according to $\alpha=0.05$ significance level.

vapour permeability of the fabrics produced from PES and r-PET fibers were found close and the difference between them was found insignificant.

\section{Vertical wicking results of the fabrics}

The water vertical wicking speed of PES and r-PET fabrics is given in figure 4 .

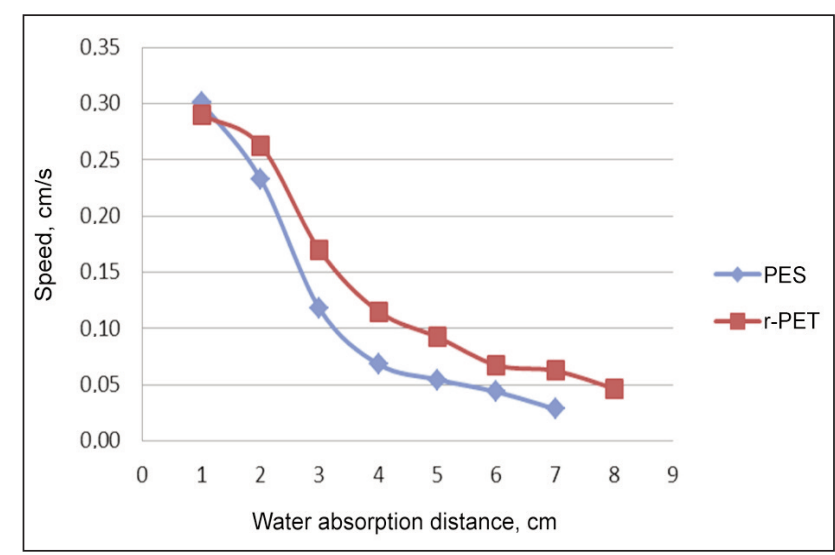

Fig. 4. Water vertical wicking speed of PES and r-PET fabrics

In this measurement, bottom end of fabric sample is immersed into the distilled water and the height of water transmission is measured. Therefore, water can be transferred through the all capillary tubes in the test area. Quantity of the test liquid is high enough for the sensitive determination of the differences in capillary forces.

As figure 4 was analysed, it can be pointed out that due to the deterioration in surface structure, r-PET fibers are more fractured and the number of capillary tubes between fibers increases. For this reason, performance of r-PET fabric was found better than PES fabric in this test. 


\section{Drying rate of the fabrics}

Results of drying test were given in figure 5 . In this measurement, although the weight of water added to the fabric is equal to $30 \%$ of the dry sample weight, water evaporating rate of the r-PET fabric was found higher than conventional PES fabric. It is related with the higher surface area of the r-PET fibers that increases the evaporation.

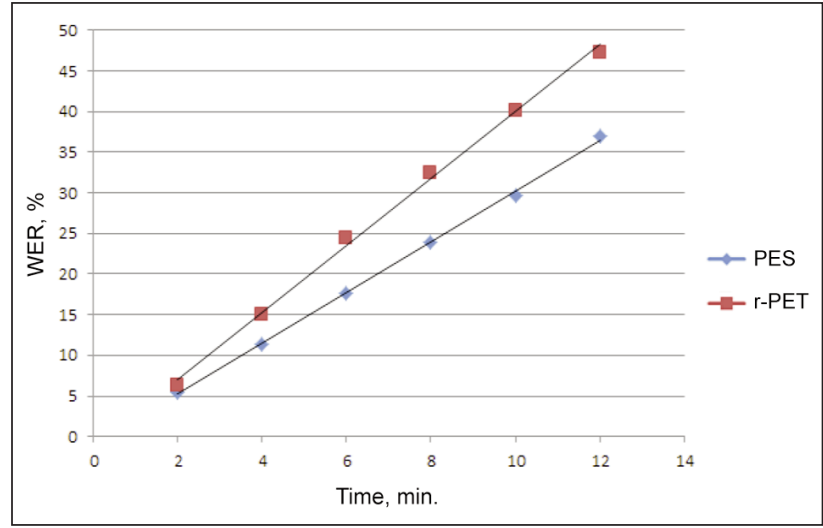

Fig. 5. Water evaporating rate change versus time

\section{CONCLUSION}

Liquid moisture management property is especially important in sportswear, where exposure to perspiration is intense. Research in this subject is more focused on high technological fibrous products such as channelled fibers and micro fibers. Recycling based researches and looking for new applications of such products is increasing worldwide.

Previous studies shows that there are numerous studies on Moisture Management Properties of products produced from polyester fiber but there is a huge need for more studies on recycled products. This study aims to compare moisture management, liquid moisture transfer and water vapour permeability properties of $r-P E T$ and conventional polyester fabrics. For this purpose, different measurement systems including conventional and new generation methods were used.
Polyester fibers are hydrophobic; therefore, water is transferred to the outer layers from the surface of the fibers by capillary forces. Due to the mechanical and thermal effects, fiber surface is rougher in r-PET fibers. That increases its wettability, capillary transfer performance and its drying rate. However, each of these differences in water transfer properties can be detected by different test procedures.

According to the MMT Instrument results, both fabrics were classified as fast absorbing and quick drying fabrics category and identified as "good" in terms of overall moisture management properties. Absorption rate differences were found between the PES and r-PET fabrics. Static Immersion test was used to measure wettability differences between the fabrics. However water absorption capacity differences could not be distinguished.

Water vapour permeability in synthetics is mostly related with the porosity of the fabrics. Fiber deteriorations in r-PET fibers changes surface characteristics of the fabrics; however it does not change porosity of the fabric in macro scale. For this reason, water vapour permeability of the both fabrics was found close to each other.

Liquid transport of conventional and r-PET fabrics were detect by wicking test which is a sensitive measurement method and found significant differences between them. Drying rate test which demonstrates the overall effectiveness of sweat removal by evaporation was used to determine the water evaporation rate of the fabrics. According to results the r-PET fabric was found higher than conventional PES fabric because of the higher evaporation speeds of the r-PET fabric obtained by higher surface area.

As recycling, sustainability and environmental pollution was considered, it should be underlined that, the fabrics produced from r-PET fibers have competitively good moisture management properties which can be used in textile goods more commonly.

\section{ACKNOWLEDGEMENT}

This research was supported by Ege University as 2015/MÜH/016 coded BAP Project.

\section{REFERENCES}

[1] Okur, A., Küçüka, S., Kaplan, S., Giysi Termal Konforunun Belirlenmesine Yönelik Bir Yöntem Geliştirilmesi, TUBITAK (The scientific and technological research council of Turkey) project, Project Number: 107M200, 2008

[2] Güneşoğlu, S., Sportif Amaçlı Giysilerin Konfor Özelliklerinin Araştırılması, Doktora Tezi, Uludağ Üniversitesi, Fen Bilimleri Enstitüsü, Bursa, 2005

[3] Yao, B.G., Li, Y., Hu, J.Y., Kwok, Y.L., Yeung, K.W., An Improved Test Method for Characterizing the Dynamic Liquid Moisture Transfer in Porous Polymeric Materials, In: Polymer Testing, 2006, 25, 677-689

[4] Yoo, S., Barker, R.L., Moisture Management Properties of Heat-Resistant Workwear Fabrics - Effects of Hydrophilic Finishes and Hygroscopic Fiber Blends, In: Textile Research Journal, 2004, 74, 11, 995-1000

[5] Sarkar, M., Fan, J., Szeto, Y., Tao, X., Biomimetics of Plant Structure in Textile Fabrics for the Improvement of Water Transport Properties, In: Textile Research Journal, 2009, 79, 7, 657-668

[6] Hu, J., Li Y., Yeung, K., Wong, A.S.W., Xu, W., Moisture Management Tester: A Method to Characterize Fabric Liquid Moisture Management Properties, In: Textile Research Journal, 2005, 75, 1, 57-62

[7] Niwa, M., Water Vapor Permeability of Underwear, In: J. Jpn. Res. Assn. Textile End Uses, 1968, 9, 446-450

[8] Avci, H., Yeni Liflerden Mamul Çorapların Konfor Özellikleri. Yüksek Lisans Tezi, İstanbul Teknik Üniversitesi, Fen Bilimleri Enstitüsü, İstanbul, 2007 
[9] Marmarali, A., Oğlakçioğlu, N., Giysilerde Isıl Konfor, 11. Ulusal Tesisat Mühendisliği Kongresi, Bildiri Kitabı, İzmir, 2013, 1957-1963

[10] Matsudaira, M., Kondo, Y., The Effect of a Grooved Hollow in a Fibre on Fabric Moisture- and Heat-transport Properties, In: The Journal of the Textile Institute, 1996, 87, 409-416

[11] Özdil, N., Süpüren, G., Özçelik, G., Pruchova J., A Study on the Moisture Transport Properties of the Cotton Knitted Fabrics in Single Jersey Structure, In: Tekstil ve Konfeksiyon, 2009, 19, 3, 218-223

[12] Süpüren, G., Oğlakçığlu, N., Özdil, N., Marmaralı, A., Moisture Management and Thermal Absorptivity Properties of Double-Face Knitted Fabrics, In: Textile Research Journal, 2011, 81, 13, 1320-1330

[13] Wardman, R.H., Abdrabbo, A., Effect of Plasma Treatment on the Spreading of Micro Drops through Polylactic Acid (PLA) and Polyester (PET) Fabrics, In: AUTEX Research Journal, 2010, 10, 320-326

[14] Özdil N., Süpüren G., Özçelik, G., Moisture Management Properties of Fabrics Knitted with Different Materials (Part 2), In: Tekstil Teknoloji, 2009, 14, 157, 114-121

[15] Özdil N., Süpüren G., Özçelik, G., Moisture Management Properties of Fabrics Knitted with Different Materials (Part 1), In: Tekstil Teknoloji, 2009, 14, 156, 172-186

[16] Awaja, F., Pavel, D., Recycling of PET, In: European Polimer Journal, 2005, 41, 1453-1477

[17] Mannhart, M., Pet Siselerden Filament Iplik, In: Melliand Türkiye Sayısı, 1998, 3, 166-169

[18] Mancini, S.D., Schwartzman, J.A.S., Nogueira, A.R., Kagohara, D.A., Zanin, M., Additional Steps in Mechanical Recycling of PET, In: Journal of Cleaner Production, 2009, 18, 92-100

[19] Telli, A., Özdil, N., r-PET Lifleri ve Karışımlarından Üretilen Ipliklerin Özellikleri, In: Tekstil ve Konfeksiyon, 2013, 23, 1

[20] Telli, A., Özdil, N., Lint Generation of the Yarns Produced PET Fibers, In: International Congress of Innovative Textiles, Çorlu, Turkey, 2011

[21] Telli, A., Özdil, N., Effect of Recycled PET Fibers on the Performance Properties of Knitted Fabrics, In: Journal of Engineered Fibers and Fabrics, 2015, 10, 2, 47-60

[22] Oktem, T., Polyester Atıkların Değerlendirilmesi, In: Tekstil ve Konfeksiyon, 1998, 6, 396-400

[23] Ahmad, S., Mulyadi, I.M.M., Ibrahim, N., Othman, A.R., The Application of Recycled Textile and Innovative Spatial Design Strategies for a Recycling Centre Exhibition Space, In: Procedia - Social and Behavioral Sciences, 2016, 234, 525-535

[24] Hatamlou, M., Süpüren, G., Özgüney, A.T., Özdil, N., Liquid Moisture Transport: Usage of r-Pet Instead of Conventional PET, In: International Technological Sciences and Design Symposium, Giresun, Turkey, 2018, $1399-1412$

[25] AATCC 195 - Liquid Moisture Management Properties of Textile Fabrics

[26] SDL Atlas. Water \& Vapor Resistance, Available at: https://sdlatlas.com/products/mmt-moisture-managementtester\#product-details [Accessed June 2018]

[27] Moisture Management Tester - Operation Manuel

[28] Kanat, Z.E., Özdil, N., Effect of Fiber Types on the Moisture Management Properties of PES Fabrics, In: International Conference of Applied Research in Textile, CIRAT 4, Monastir, Tunisia, 2010

[29] ISO Standard 11092 Textiles - Physiological Effects - Measurement of Thermal and Water-Vapour Resistance under Steady-State Conditions.

[30] TS EN 14697 Textiles - Terry towels and terry towel fabrics - Specification and methods of test

[31] BS 3449: Method for resistance of fabrics to water absorption (Static immersion test)

Authors:

MEHDI HATAMLOU ${ }^{1}$, ARIF TANER ÖZGÜNEY' ${ }^{1}$, NILGÜN ÖZDIL GAMZE SÜPÜREN MENGÜÇ²

${ }^{1}$ Ege University, Department of Textile Engineering, İzmir, Turkey

${ }^{2}$ Ege University, Emel Akın Vocational Training School, İzmir, Turkey

Corresponding author:

GAMZE SÜPÜREN MENGÜÇ

e-mail: gamze.supuren.menguc@ege.edu.tr 